\title{
SUPREMO GERA POLÊMICA AO DECIDIR SOBRE JULGAMENTO DE CONTAS DE PREFEITOS
}

Coluna publicada em 23.8.2016: <https://www.conjur.com.br/2016-ago-23/ contas-vista-stf-gera-polemica-decidir-julgamento-contas-prefeitos $>$

A aproximação das eleições municipais traz muitas questões interessantes e relevantes no campo do Direito Financeiro, e é sempre bom estar atento a elas, pois, afinal, elegeremos aqueles que vão cuidar do dinheiro que é de todos nós.

Recentemente $^{1}$ veio a debate, em nossa Suprema Corte, questão envolvendo decisão de tribunal de contas que julgou irregulares as contas de prefeito, levando-o à inelegibilidade, em face do que estabelece a legislação eleitoral. ${ }^{2}$ Insurgiu-se o prefeito contra o ato, pondo em discussão os limites da competência e alcance das decisões dos tribunais de contas quando se tratar das contas apresentadas por prefeitos.

A decisão do STF sobre o caso despertou polêmicas e chegou a ser duramente atacada, ${ }^{3}$ sendo relevante conhecer e esclarecer as questões discutidas. Embora o

1 Sessão de 10 de agosto, processos RE 848826 e RE 729744, em repercussão geral. "Competência para julgar contas de prefeito é da Câmara de Vereadores, decide STF” (Portal de notícias $S T F-<$ www.stf.jus.br>), em 10 de agosto de 2016.

2 LC 64/1990, art. 10, inciso I, alínea $g$ (com redação dada pela LC 135/2010 - "Lei da Ficha Limpa"): "São inelegíveis para qualquer cargo os que tiverem suas contas relativas ao exercício de cargos ou funções públicas rejeitadas por irregularidade insanável que configure ato doloso de improbidade administrativa, e por decisão irrecorrível do órgão competente, salvo se esta houver sido suspensa ou anulada pelo Poder Judiciário, para as eleiçôes que se realizarem nos 8 (oito) anos seguintes, contados a partir da data da decisão, aplicando-se o disposto no inciso II do art. 71 da Constituição Federal, a todos os ordenadores de despesa, sem exclusão de mandatários que houverem agido nessa condição".

3 Em nota pública, a Associação dos Membros dos Tribunais de Contas do Brasil (Atricon) referiu-se ao caso como "uma das maiores derrotas da República Brasileira após a redemocratização" 
acórdão não tenha sido publicado, o que impede uma análise da decisão de forma precisa e detalhada, o tema objeto da controvérsia merece ser mais bem conhecido, e o que se pretende é trazer noções acerca do caso, ainda que simples, e assim melhor compreendê-lo.

Os tribunais de contas, órgãos cuja importância é cada vez maior e mais notada em nosso Estado Democrático de Direito, o que já foi ressaltado por mais de uma vez neste espaço, ${ }^{4}$ têm suas atribuições previstas na Constituição, sendo os grandes responsáveis pela fiscalização contábil, financeira e orçamentária da administração pública.

O art. 71 da Constituição Federal, ${ }^{5}$ ao descrever as funções que exercem como órgão que presta auxílio ao Poder Legislativo ${ }^{6}$ no controle externo da administração pública, estabelece que lhes compete, entre outras funções: a) apreciar as contas prestadas anualmente pelo Chefe do Poder Executivo, mediante parecer prévio; e b) julgar as contas dos administradores e demais responsáveis por dinheiros, bens e valores públicos, incluindo ainda todos aqueles que derem causa a perda, extravio ou irregularidades que resultem em prejuízo ao erário público.

No que se refere à primeira delas, os tribunais de contas exercem atribuições que se inserem no âmbito de sua função consultiva, uma vez que se está diante do julgamento das chamadas "contas de governo", ou seja, das contas anuais, que explicitam a atividade financeira do ente federado no exercício financeiro findo, e que tem no Chefe do Poder Executivo o responsável por sua apresentação para julgamento perante o Poder Legislativo, titular do controle externo da administração pública.

Sendo assim, a função dos tribunais de contas limita-se a emitir um parecer, sugerindo o resultado do julgamento - as contas poder ser aprovadas, aprovadas

e afirmou que a "decisão representa um imenso retrocesso no controle das contas governamentais" e que "vai na contramão dos esforços populares e suprapartidários de combate à corrupção e de moralidade na gestão dos recursos públicos", pois "retira dos Tribunais de Contas a competência para julgar as contas de prefeito que age como ordenador de despesas", selando "a vitória da injustiça e da impunidade" (<http://www.atricon.org.br/imprensa/destaque/nota-publica-sobre-o-re-848826/>). No mesmo sentido posicionou-se a Associação Nacional do Ministério Público de Contas (AMPCON) e outras entidades que congregam diversos atores no âmbito do controle das contas públicas (<http://www.ampcon.org.br/noticia/nota-publica-em-defesa-da-lei-da-ficha-limpa-e-das-competencias-dos-tribunais-de-contas $>$ ).

4 Para citar algumas colunas sobre o tema, destaco Tribunais de Contas são guardiōes do dinheiro público, p. 317-322, e Julgamento das contas do governo precisa ser feito com rigor, p. 329-334.

5 Que se aplica, por simetria, aos demais entes da federação.

6 O que não faz dele um órgão com vínculos de subordinação a este Poder, pois lhe é assegurada autonomia e independência para exercer esta missão. 
com ressalvas ou reprovadas -, que deverá ser proferido pelo Poder Legislativo competente.

No que tange à segunda função anteriormente mencionada - julgamento de contas dos administradores e responsáveis por recursos públicos -, os tribunais de contas "julgam” as contas, proferindo decisões definitivas, de natureza administrativa, podendo considerá-las regulares, regulares com ressalvas ou irregulares. São as chamadas "contas de gestão".

As contas de governo são prestadas anualmente pelo Chefe do Poder Executivo, e têm por finalidade demonstrar as atividades financeiras da administração pública do ente federado pelo qual é responsável no exercício financeiro a que se referem, evidenciando os resultados da ação governamental, com o cumprimento dos programas orçamentários no período, o nível de endividamento, destinação dos recursos às áreas prioritárias e cumprimento dos deveres de gastos mínimos obrigatórios, observância dos limites de gastos com pessoal e demais informações que permitam avaliar globalmente as contas e a aderência ao planejamento governamental. Tem como foco a avaliação da gestão de forma ampla, em seu aspecto macro, mitigando a relevância de minúcias e aspectos formais. $\mathrm{O}$ julgamento dessas contas é, portanto, suscetível de avaliação de cunho político, que leve em consideração critérios de conveniência e oportunidade. ${ }^{7}$ Nesses casos, há o parecer prévio do tribunal de contas para subsidiar e dar elementos para que o Poder Legislativo tome a decisão. Parecer que não tem caráter vinculativo, mas, no caso dos Municípios, exige dois terços dos votos da Câmara de Vereadores para que seja possível adotar decisão diversa da que consta do parecer (CF, art. 31, $\$ 2^{\circ}$ ).

As contas de gestão (ou contas dos ordenadores de despesas) não são necessariamente anuais, têm por finalidade demonstrar a aplicação de recursos públicos praticados por aqueles que foram responsáveis por geri-los, e nelas serão observadas a legalidade, a legitimidade e a economicidade dos atos praticados, regularidade e conformidade de procedimentos, identificando e apurando eventuais lesões ao erário e atos de improbidade administrativa. Tais contas são submetidas a julgamento técnico pelos tribunais de contas, que poderão, em caso de irregularidade constatada, aplicar sanções, como as multas, por exemplo.

Ocorre que, em muitos casos, especialmente nos Municípios de menor porte, os prefeitos atuam na condição de administradores e responsáveis por recursos públicos, agindo como ordenadores de despesas e praticando atos de gestão financeira, o que levou os tribunais de contas a, no exercício de suas funçôes, julgar suas contas.

7 Como bem explicita J. R. Caldas Furtado, com destaque para o texto "Os regimes de contas públicas: contas de governo e contas de gestão”, publicado na Revista do TCU, n. 109, p. 61-89. 
É o que se verifica quando firmam convênios para receber recursos de outros entes da federação, especialmente da União, por meio das transferências voluntárias, devendo administrá-los e prestar contas junto ao ente que lhes transferiu, e que se submetem ao sistema de fiscalização próprio.

Nesses casos, os prefeitos acabam exercendo uma dupla função, pois, além de gerenciarem diretamente recursos públicos, e, portanto, ficando responsáveis pelos atos a eles relacionados, também continuam com o dever de apresentar as contas anuais da administração pública para julgamento perante o Poder Legislativo, mediante parecer prévio, de natureza opinativa, do tribunal de contas competente.

Isto faz com que a gestão municipal se submeta a um controle de dupla natureza. Hélio Mileski bem explica que "o Prefeito Municipal é mais que o condutor político do Município, ele também é o administrador, o gestor dos bens e dinheiros públicos, assumindo uma dupla função - política e administrativa”. E enfatiza, com base em decisões do Superior Tribunal de Justiça, que "justamente por isso, o Poder Judiciário, quando examina o tema, tem decidido reiteradamente, sob o argumento de que, sendo responsável por uma dupla função, o Prefeito Municipal também se submete a um duplo julgamento: um político, perante o Parlamento, precedido de parecer prévio, e outro técnico, a cargo do Tribunal de Contas". ${ }^{8}$

Há, pois, que se reconhecer existirem decisões de natureza e regime jurídico diversos, a que podem se sujeitar os prefeitos: a) o julgamento técnico-administrativo das "contas de gestão", a cargo do tribunal de contas; e b) o julgamento político-administrativo das "contas de governo", sob responsabilidade da Câmara de Vereadores, à luz do parecer emitido pelo tribunal de contas.

Nessa linha, Caldas Furtado aduz que o regime de julgamento de contas deve ser "determinado pela natureza dos atos a que elas se referem, e não por causa do cargo ocupado pela pessoa que os pratica. Para os atos de governo, haverá o julgamento político; para os atos de gestão, o julgamento técnico".

A recente decisão do Supremo Tribunal Federal provocou divergência entre os Ministros, tendo o relator, Min. Luís Roberto Barroso, votado no sentido de reconhecer a competência dos Tribunais de Contas para julgar em definitivo as contas de gestão dos prefeitos, o que levaria à inelegibilidade. A maioria dos Ministros (6x5), no entanto, divergiu, ficando vencido o relator, e prevalecendo a tese de que

8 MILESKI, Helio Saul. O controle de gestão pública. São Paulo: RT, 2003. p. 274.

9 "Os regimes de contas públicas: contas de governo e contas de gestão", publicado na Revista do TCU, n. 109, p. 75. 
as contas de prefeito submetem-se ao julgamento exclusivo pela Câmara de Vereadores, não sendo possível reconhecer a inelegibilidade em face da decisão do tribunal de contas, e nesse sentido foi redigido um dos verbetes das teses de repercussão geral: "Para os fins do artigo 1\%, inciso I, alínea $g$, da Lei Complementar 64/1990, alterado pela Lei Complementar 135/2010, a apreciação das contas de prefeito, tanto as de governo quanto as de gestão, será exercida pelas câmaras legislativas, com auxílio dos tribunais de contas, cujo parecer prévio somente deixará de prevalecer por decisão de dois terços dos vereadores". ${ }^{10}$

No que se refere à inelegibilidade, vê-se haver divergência de entendimento, já tendo o Tribunal Superior Eleitoral (TSE) decidido que "a desaprovação das contas pelo Tribunal de Contas não é suficiente para que se conclua pela inelegibilidade do candidato", ${ }^{11}$ e entendia o Ministro Relator Marcelo Ribeiro que o critério de determinação da competência é da pessoa que tem os atos de gestão julgados, pelo que as do Chefe do Executivo Municipal seriam apreciadas em caráter final pela Câmara Municipal; unicamente após sua decisão é que se aplicaria a sanção da inelegibilidade, nos termos da legislação eleitoral (LC 64/1990). Considera que o artigo $71 \mathrm{da}$ Constituição, que distingue as contas anuais das contas pelos atos de gestão (diretamente praticados para ordenar despesas), não se aplica simetricamente aos Municípios da mesma forma que incide sobre a gestão de outros entes, em face do que dispõe o art. 31 da Constituição, que entende conferir competência exclusiva do Poder Legislativo municipal". ${ }^{12}$

É necessário conhecer o exato teor da recente decisão do STF e seu alcance, pois são muitos os questionamentos e consequências que dela podem advir.

Um dos principais é a índole política das Câmaras Municipais, que incluiriam a decisão sobre matérias técnicas da execução orçamentária em seu raio de ação de forma exclusiva para efeitos da aplicação de determinadas sanções legais ao administrador municipal. Se o sentido da atividade política do controle externo é claro para a análise das contas anuais, em que se avaliam aspectos políticos da gestão municipal com o fim de concluir pela sua adesão ao interesse público, isso não se

10 Sessão de 17 de outubro de 2016. Disponível em: <http://www.conjur.com.br/2016-ago-17/ supremo-volta-discutir-define-tese-rejeicao-contas $>$. A segunda tese de repercussão geral estabeleceu que "Parecer técnico elaborado pelo Tribunal de Contas tem natureza meramente opinativa, competindo exclusivamente à Câmara de Vereadores o julgamento das contas anuais do chefe do Poder Executivo local, sendo incabível o julgamento ficto das contas por decurso de prazo".

11 Recurso Especial Eleitoral 29535.

12 TSE, REsp Eleitoral 29535, rel. Min. Marcelo Ribeiro, p. 5. 
observa de forma tão nítida em atos de ordenação de despesa nos quais a observância dos requisitos legais de validade do ato deveria ser o critério mais adequado de decisão, de acordo com sua legalidade, legitimidade e economicidade.

E também, muitas vezes, os tribunais de contas, no exercício de atos de fiscalização, em inspeções ou auditorias, constatam condutas que geram dano ao erário, caso em que promovem a tomada de contas especial e julgam as contas do agente público responsável, aplicando as penalidades e tomando as providências cabíveis para ressarcir os cofres públicos. Não é incomum ser o prefeito o agente público infrator, e a submissão a julgamento exclusivamente pela Câmara de Vereadores, nesse caso, pode reduzir ou mesmo inviabilizar essa ação dos tribunais de contas, o que é extremamente prejudicial ao efetivo controle da gestão das finanças públicas. Não só porque as Câmaras de Vereadores podem, como efetivamente se tem observado, levar décadas para concluir o julgamento das contas, ${ }^{13}$ como serem suscetíveis de influências políticas que levem a uma decisão pouco técnica e não absolutamente isenta. Em recente artigo, Doris Coutinho ressalta a gravidade da situação, e bem lembra que "questôes técnicas sobre atos concretos de ordenação do gestor, como o não pagamento de fornecedores para locupletar-se dos valores ou a não apresentação de notas fiscais, por exemplo, estarão sujeitas à absolvição política". ${ }^{14}$ Sem contar que, no mais das vezes, as Câmaras de Vereadores não são dotadas de capacidade técnica que permita uma avaliação adequada das contas.

É importante lembrar que os tribunais de contas têm poderes sancionatórios e instrumentos capazes de promover o ressarcimento de prejuízos causados ao erário, o que não está previsto para as Câmaras de Vereadores, gerando o receio, a depender dos efeitos da decisão tomada pelo STF, que a punição dos infratores e a recuperação dos danos possam ser seriamente prejudicadas.

Há outros temas controversos neste caso, sendo muitas as questões, mas não há como trazê-las todas neste curto espaço. Mas é importante ressaltar que, na atual conjuntura em que estamos, em que o combate à corrupção tem se fortalecido cada vez mais, e nosso país está demonstrando que o lugar dos corruptos é a cadeia, é preciso cautela para que não se enfraqueça o controle externo com a redução dos poderes dos tribunais de contas, o que pode fragilizar o sistema de responsabilização dos agentes públicos e aumentar a impunidade.

13 O Município de Campinas, terceiro maior do Estado de São Paulo, analisou as contas pela última vez em 2002, registra a Revista Veja (Fichas-sujas ostentação, edição 2492, ano 49, n. 34, 24 de agosto de 2016, p. 55).

14 COUTINHO, Doris de Miranda. Uma ideia falsa, porém clara e precisa, publicada no jornal O Estado de S.Paulo, blog de Fausto Macedo, em 11 de agosto de 2016. 